\begin{tabular}{c} 
JCEBT, vol 5(1) Maret 2021 ISSN 2549-6379 (Print) $\quad$ ISSN 2549-6387 (Online) \\
JCEBT \\
Oournal of Civil Engineering, Building and Transportation) \\
Available online http://ojs.uma.ac.id/index.php/jcebt \\
\hline
\end{tabular}

\title{
Analisis Sistem Informasi Penjadwalan Waktu dan Pengendalian Proyek Gedung Perkantoran dan Gudang Suzuya
}

\section{System Analysis of Time Scheduling Information and Project Control of Office Building and Suzuya Buildings}

\author{
Irwan ,Melloukey Ardan, Windy Anisa Putri \\ Program Studi Teknik Sipil, Fakultas Teknik \\ Universitas Medan Area, Indonesia
}

Coresponding author: windyanisap@gmail.com

\begin{abstract}
Abstrak
Pengendalian proyek merupakan salah satu fungsi dari manajemen proyek yang sangat mempengaruhi hasil akhir proyek, pengendalian mempunyai tujuan utama meminimalisasi segala penyimpangan yang dapat terjadi selama proses berlangsungnya proyek. Program aplikasi komputer dewasa ini sangat mempermudah para manajemen rekayasa konstruksi dalam memasukkan data proyek, mengelola aktivitas proyek, pengendalian proyek, laporan proyek maupun pengontrolan aktivitas kegiatan proyek diantaranya menyangkut sumber daya pada proyek tersebut. Penelitian ini merencanakan jadwal suatu proyek menggunakan program aplikasi Microsoft Project 2010. Dengan tujuan penelitian ini yaitu untuk mengetahui apakah schedule rencana sesuai dengan schedule pelaksanaan dan juga untuk mengetahui faktor yang menjadi kendala pada saat pelaksanaan proyek. Dari hasil analisa pengendalian \& penjadwalan Proyek Pembangunan Gedung Perkantoran dan Gudang Suzuya Medan dapat disimpulkan bahwa Jadwal Rencana tidak sesuai dengan Jadwal Pelaksaan di Lapangan, dan diketahui pekerjaan yang menujukkan jalur kritis seperti: pekerjaan pendahuluan, pekerjaan pondasi, dan pekerjaan pemasangan dinding. Adapun faktor yang menjadi kendala pada saat pelaksanaan proyek adalah sering terjadi keterlambatan pengiriman barang sehingga pekerjaan tertunda dan menjadi mundur dari jadwal yang telah ditentukan.
\end{abstract}

Kata Kunci: Konstruksi, Jadwal, Kendali, Informasi

\begin{abstract}
Project control is one of the functions of project management that greatly influences the final outcome of the project. Control has the main objective of minimizing any irregularities that can occur during the project's ongoing process. Today's computer application program makes it very easy for construction engineering management to enter project data, manage project activities, project control, project reports and control of project activities including the resources involved in the project. This study plans a project schedule using the Microsoft Project 2010 application program. The purpose of this study is to find out whether the planned schedule is in accordance with the implementation schedule and also to find out the factors that become obstacles during project implementation. From the analysis of the control \& scheduling of the Suzuya Medan Office Building and Warehouse Development Project, it can be concluded that the Schedule Plan is not in accordance with the Field Implementation Schedule, and it is known that the work shows critical paths such as: preliminary work, foundation work, and wall mounting work.
\end{abstract}

Keywords: Construction, Schedule, Control, Information

How to Cite: Windy,Irwan,Melloukey Ardan, Analisis Sistem Informasi Penjadwalan Waktu dan Pengendalian Proyek Gedung Perkantoran dan Gudang Suzuya. JCEBT (Journal of Civil Engineering, Building and Transportation). 5 (1): $37-45$ 


\section{PENDAHULUAN}

Manajemen merupakan sebuah proses, jadi butuhkan masukkan terhadap proses tersebut. Sebagai masukannya adalah berbagi macam sumber daya atau resources, yakni manusia, material, modal, mesin - mesin dan metode kerja, apabila ke dalam suatu manajemen diberikan masukan - masukan (input) secukupnya, maka diharapkan manajemen dapat menghasilkan keluaran - keluaran (output), itu tercapainya tujuan atau sasaran sebagaimana diharapkan. (Nurhayati, 2013).

Manajemen adalah kemampuan untuk memperoleh hasil dalam rangka pencapaian tujuan melalui kegiatan sekelompok orang. Untuk itu, tujuan perlu ditetapkan terlebih dahulu, sebleum melibatkan sekelompok orang yang mempunyai kemampuan atau keahlian dalam rangka pencapaian tujuan yang telah ditetapkan. Dengan kata lain, manjemen berfungsi untuk melaksakana semua kegiatan yang diperlukan dalam pemcapaian tujuan dengan batas - batas tertentu. (Widisanti dkk, 2013).

Manajemen sebagai kumpulan orang (management as a people/group of people) adalah suatu istilah yang dipakai dalam arti kolektif untuk menujukkan jabatan kepemimpinan di dalam organisasi antara lain kelompok pimpinan atas, kelompok pimpinan tengah, dan kelompok pimpinan bawah. (Kamarwan, 1998).

Sistem Informasi (SI) adalah kombinasi dari teknologi informasi dan aktivitas orang yang menggunakan teknologi itu untuk mendukung operasi dan manajemen. Dalam arti yang sangat luas, istilah sistem informasi yang sering digunakan merujuk kepada interaksi antara orang, proses algoritmik, data, dan teknologi. Dalam pengertian ini, istilah ini digunakan untuk merujuk tidak hanya pada penggunaan organisasi teknologi informasi dan komunikasi (TIK), tetapi juga untuk cara di mana orang berinteraksi dengan teknologi ini dalam mendukung proses bisnis. Tujuan dari sistem informasi adalah menghasilkan informasi. Sistem informasi adalah data yang diolah menjadi bentuk yang berguna bagi para pemakainya. Data yang diolah saja tidak cukup dapat dikatakan sebagai suatu informasi. Untuk dapat berguna, maka informasi harus didukung oleh tiga pilar sebagai berikut: tepat kepada orangnya atau relevan (relevance), tepat waktu (timeliness), dan tepat nilainya atau akurat (accurate). Keluaran yang tidak didukung oleh tiga pilar ini tidak dapat dikatakan sebagai informasi yang berguna, tetapi merupakan sampah (garbage).

Proyek dapat dikatakan sebagai suatu usaha untuk mecapai tujuan tertentu 
menurut (Wahana Komputer, 2005:10). Penjadwalan proyek adalah rencana pengurutan kerja untuk menyelesaikan suatu pekerjaan dengan sasaran khusus dengan saat penyelesian yang jelas. Sebelum proyek dikerjakan, perlu tahap tahap pengelolaan proyek yang meliputi perencaan, tahap penjadwalan, dan tahap pengkoordinasian. Dari tiga tahap ini, tahap perencaan dan penjadwalan adalah tahap yang paling menentukan berhasil/tidaknya suatu proyek, karena penjadwalan adalah tahap ketergantungan antara tugas yang membangun proyek secara keseluruhan.

Manajemen waktu proyek merupakan salah satu kompetensi yang harus dimiliki oleh seorang manajer proyek. Manajemen waktu proyek dibutuhkan manajer proyek untuk membantu dan mengendalikan waktu yang dihabiskan dalam menyelesaikan sebuah proyek. Dengan menerapkan manajemen waktu proyek, seorang manajer proyek dapat mengontrol jumlah waktu yang dibutuhkan oleh tim proyek untuk membangun deliverables proyek sehingga memperbesar kemungkinan sebuah proyek dapat diselaikan sesuai dengan jadwal yang telah ditentukan.

Terdapat beberapa proses yang perlu dilakukan seorang manajer proyek dalam mengendalikan waktu biaya proyek yaitu :

1. Mendefenisikan akivitas proyek adalah merupakan sebuah proses untuk mengidentifikasi setiap aktivitas yang dibutuhkan untuk mencapai tujuan proyek;

2. Urutan aktivitas proyek yang bertujuan untuk mengidentifikasi dan mendokumnetasikan hubungan antara tiap - tiap aktivitas proyek

3. Estimate aktivitas sumber daya proyek bertujuan untuk melakukan estimasi terhadap penggunaan sumber daya proyek

4. Estimasi durasi kegiatan proyek diperlukan untuk menentukan berapa lama waktu yang dibutuhkan untuk mencapai tujuan proyek

5. Membuat jadwal proyek setelah seluruh aktivitas, waktu dan sumber daya proyek terdefenisi dengan jelas, maka seorang manajer proyek akan membuat jadwal proyek. Jadwal proyek ini nantinya dapat digunakan untuk menggamabarkan secara rinci mengenai seluruh aktivitas proyek dari awal pengerjaan proyek hingga proyek diselesaikan

6. Mengontrol dan mengendalikan jadwal proyek saat kegiatan proyek 
mulai berjalan, maka pengendalian dan pengontrolan jadwal proyek perlu dilakukan. Hal ini diperlukan untuk mastikan apakah kegiatan proyek berjalan sesuai dengan yang telah direncanakan atau tidak. Setiap proses diatas setidaknya terjadi sekali dalam setiap proyek dan dalam satu atau lebih tahapan proyek.

Microsoft Project yang biasa disingkat MS Project merupakan salah satu program yang mampu mengelola data proyek. Microsoft Project merupakan bagian dari Microsoft Office Professional yang dapat terintegrasi dengan mudah pada program Microsoft Exel. Pengelolaan proyek dengan Microsoft Project terdiri dari beberapa tahap yaitu menentukan tugas (task) yang harus dikerjakan, mangatur task dalam urutan yang logis dengan memperhatikan hubunga antara task dan kendala yang dihadapi, menentukan sumber daya untuk menyelesaikan suatu tugas sehingga dapat mengevaluasi jadwal yang telah tersusun serta dapat mengontrol kemajuan proyek jika sedang berlangsung.

Berikut ini beberapa keuntungan yang dapat diproleh dengan menggunakan Microsoft Project;

1. Dapat melakukan penjawalan produk secara efektif dan efesien, karena ditunjang dengan informasi alokasi waktu yang dibutuhkan tiap proses, serta kebutuhan sumber daya untuk setiap proses sepanjang waktu.

2. Dapat diperoleh secara langsung informasi aliran biaya selama priode.

3. Mudah dilakukan modifikasi, jika dilakukan rescheduling.

4. Penyususnan jadwal produksi yang tepat akan lebih mudah dihasilkan dalam waktu yang cepat.

Tujuan yang diharapkan dari sistem ini adalah penggunaan platform atau sistem project management yang efektif dan seragam (uniform), menghilangkan duplikasi terhadap spredsheet, memudahkan pembuatan laporan konsolodasi dan memperbaiki kominikasi antara staf/karyawan. Sehingga keuntungan yang diperoleh dari sistem ini seperti informasi proyek yang up-to-date, akurat, tepat waktu, dan dipercaya, bukanlah hal yang sulit untuk dipenuhi.

Tujuan yang diharapkan dari sistem ini adalah penggunaan platform atau sistem project management yang efektif dan seragam (uniform), menghilakan duplikasi terhadap spredsheet, memudahkan pembuatan laporan konsolodasi dan memperbaiki kominikasi antara staf/karyawan. Sehingga keuntungan yang diperoleh dari sistem ini seperti informasi 
proyek yang up-to-date, akurat, tepat waktu, dan dipercaya, bukanlah hal yang sulit untuk dipenuhi.

Output atau keluaran dari suatu pekerjaan perencaan proyek menggunakan Microsft Project bisa bermacam - macam. Microsoft Project menyediakan fasilitas seperti umumnya suatu aplikasi. Maksudnya, yang sudah dibuat bisa langsung di cetak atau di print ke printer seperti biasa. Selain itu apabila memerlukan report tertentu, Microsft Project juga menyediakan berbagai macam report sesuai kebutuhan sebuah proyek.

Gant chart adalah view pertama yang muncul saat Project dibuka. Gantt Chart memperlihatkan spreadsheet dengan data kolom beserta grafik representative dari tugas - tugas di dalam project yang tersusun secara horizontal timeline.

Network Diagram (juga dinamakan logic diagram) adalah PERT chart versinya Microsoft. PERT (Program Evaluation and Review Technique) lahir pada saat pembuatan Poloris aubmarine di tahun 1950. Umumnya Nertwork Diagram hanya memperlihatkan "perjalanan" tugas - tugas yang ada di project dalam bentuk grafis saja dan tidak memperlihatkan waktu dari setiap tugas. View ini membantu anda untuk melihat bagaimana suatu tugas "menjalankan" tugas lainnya dan juga memberikan makna dimana tugas anda sekarang berada tidak terlalu berdampak pada waktu melainkan bertumpu pada berapa sisa tugas yang harus diselesaikan.

Risk Management sangat penting dalam bagian suatu poject management serta tentunya proyek selalu penuh kendala (risk).anda akan menghadapi berbagai macam kendala (risk) dimana sumber daya (resource) anda tidak mampu menanganinya, atau materialnya akan datang terlambat, atau klien anda akan berubah pikiran sehingga harus merubah banyak parameter dari isi proyek itu sendiri bahkan hampir setengah dari keseluruhan proyek harus ikut dirubah.

\section{METODE PENELITIAN}

Resource Management terdiri dari penggunaan sumber daya (resource) secara bijak. Seorang project manager menentukan sumber daya (resource) yang tepat yang kemudian menugaskan seseorang dengan waktu dan beban kerja yang pantas, yang kemudian juga tetap waspada akan kerja lembur atau shift di dalam schedule yang bisa mengakibatkan suatu sumber daya (resources) menjadi terlalu padat, dan juga pada saat kelangsungan proyek sang project manager membuat perubahan perubahan untuk menjaga keseluruhan resources agar tetap produktif. Di Project, alat - alat sudah tersedia seperti halnya resources graph (dulunya disebut 
Windy,Irwan,Melloukey Ardan.(2021). Analisis Sistem Informasi Penjadwalan Waktu dan Pengendalian Proyek Gedung Perkantoran dan Gudang Suzuya

hidrogram) dan resources usage chart yang menggambarkan beban kerja sumber daya (resources workload) itu.

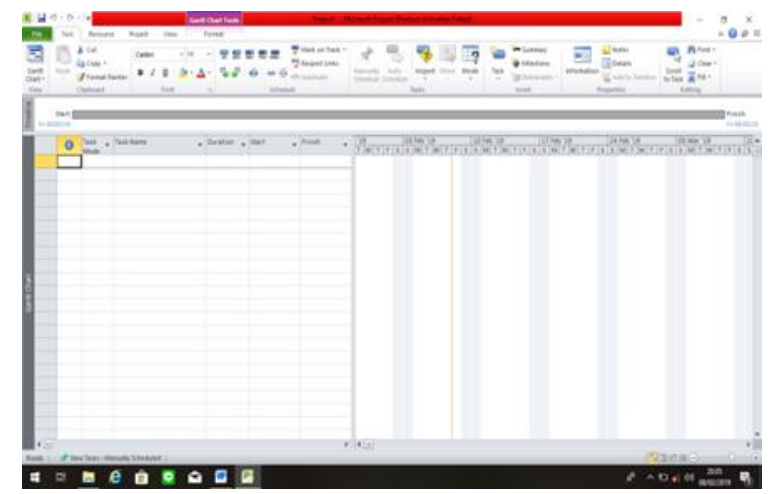

Gambar 1. Tampilan Awal Microsoft Project Sumber : Program Microsoft Project

Resource

Dalam Microsoft Project, sumber daya yang terlibat dalam sebuah proyek meliputi sumber daya manusia dan material. Resource ini akan mempuyai tugas sebagai pelaksana proyek. Untuk menentukan resource terlebih dahulu harus memiliki daftar resource yang akan digunakan. Daftar resource tersebut disebut dengan resource sheet. Prosedur untuk mengaktifkan adalah klik menu view Resource Sheet.

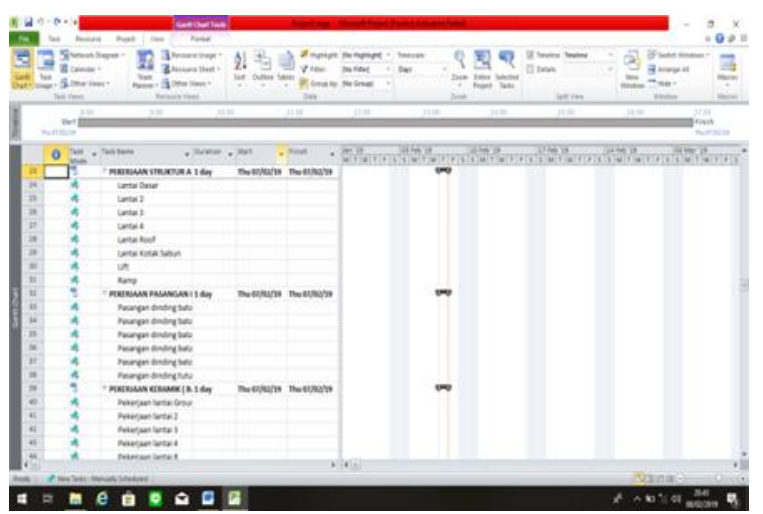

Gambar 2. Tampilan Pemberian Sumber Daya Sumber : Program Microsoft Project

\section{HASIL DAN PEMBAHASAN}

Tahapan Penggunaan Microsoft Project sebagai Pengendalian Waktu Pekerjaan Proyek. Untuk mempermudah penjadwalan pekerjaan proyek kita bisa menggunakan Microsoft Project ini, penulis sebelumnya telah mengumpulkan data proyek dalam bentuk Microsoft Excel.

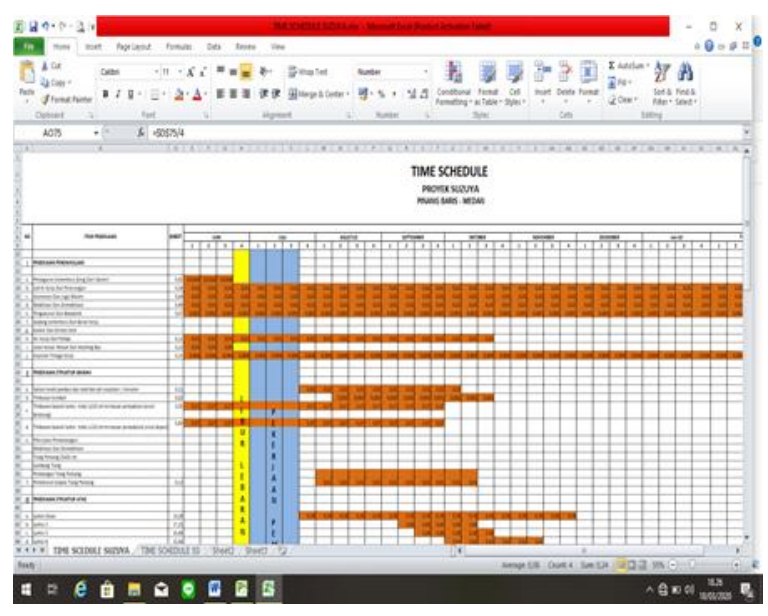

Gambar 3. Penjadwalan Dalam Microsoft Excel Sumber : Microsoft Excel

Setelah pekerjaan kurva $S$ pada Microsft Excel selanjutnya buka aplikasi Microsoft Project 2010 dan tentukan waktu mulai proyek hingga akhir proyek.

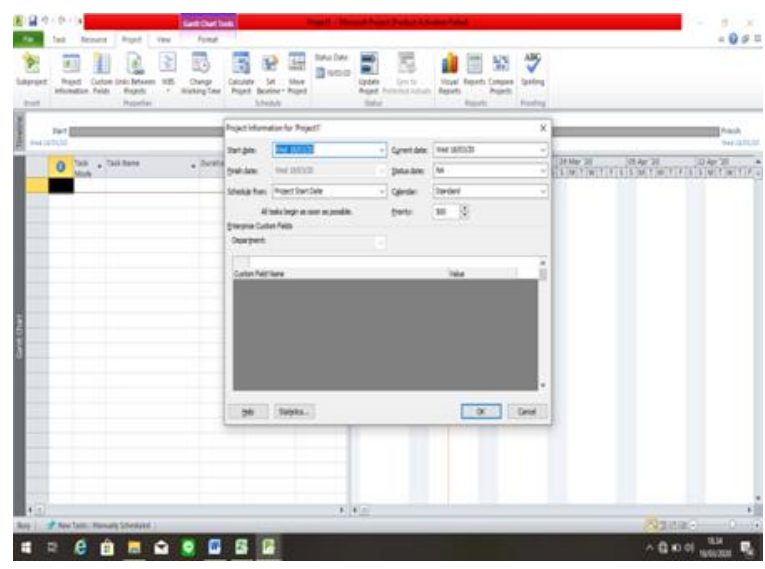

Gambar 4. Pengaturan waktu mulai proyek dan akhir pekerjaan proyek

Sumber : Microsoft Project 
Untuk membuat penganturan waktu mulai dan akhir pekerjaan proyek dapat diklik pada menu bar "Project" kemudian klik pada "Project Information" maka dapat di isi waktunya.

Jika waktu mulai dan akhir pekerjaan proyek sudah di isi maka selanjutnya menentukan hari kerja dan jam kerja

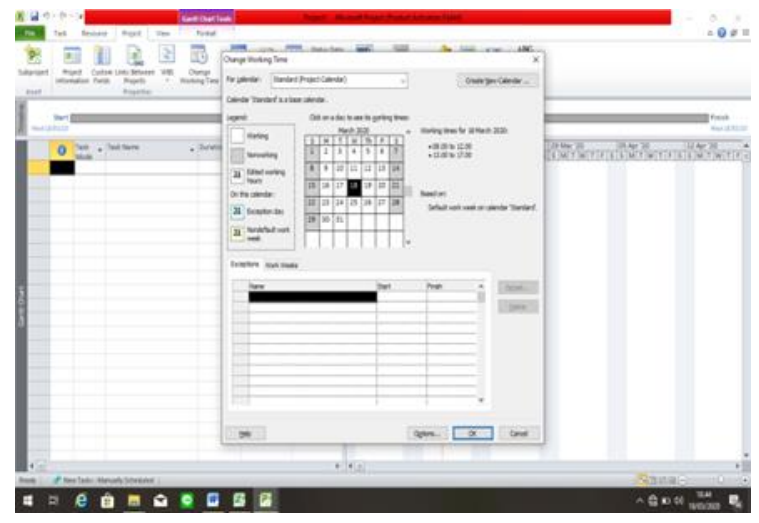

Gambar 5. Pengaturan hari kerja dan jam kerja Sumber : Microsoft Project

Gambar 5 adalah penganturan hari dan jam kerja dapat dilakukan pada menu bar "Project" kemudian pilih "Change Warking Time”. Di menu ini dilakukan pengisian jadwal kerja sesuai ketetapan proyek.

Pada proyek pembangunan gedung perkantoran dan gudang suzuya medan terdapat adanya jadwal proyek pada bulan Juni untuk diadakankan nya hari libur Idul Fitri maka dapat kita atur hari kerjanya pada tabel dengan menu "Exceptions" ini keterangan misalkan Hari libur Idul Fitri. Setelah isi keterangan maka di pilih hari awal libur pada "start" dan akhir libur kerja "finish" kemudian klik "ok".
Selanjutnya pada halangan Microsoft project isi data sesuai yang telah di kerjakan pada halaman lembar kerja Microsoft excel terlihat pada gambar 6.

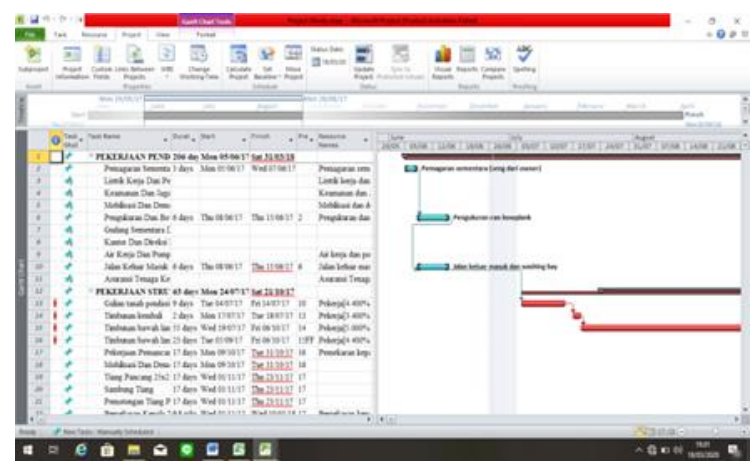

Gambar 6. Lembar Kerja Microsoft Project Sumber : Microsoft Project

Pada "Task Name" di isi daftar pekerjaan dan kemudian di isi durasi peritem pekerjaan, setelah seluruh data terisi dan ditentukan alur pekerjaan makan akan terlihat diagram batang yang berwarna merah yang menunjukkan bahwa item pekerjaan tersebut berada pada jalur kritis. Dengan demikian adanya jalur kritis maka mempermudah pengendalian waktu pekerjaan. Sehingga kendala pada item pekerjaan di jalur kritis dapat di atasi sebelumnya agar proyek tetap berjalan dengan baik.

Berikut ditampilkan time schedule keseluruhan berupa Barchat dan network diagram untuk aplikasi Microsoft Project pada Proyek Gedung Perkantoran Suzuya Medan,terlihat pada gambar 7 dibawah ini. 


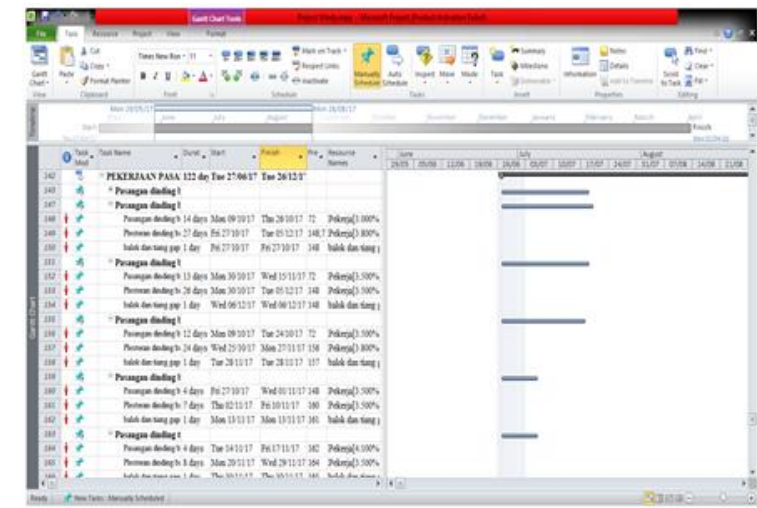

Gambar 7. Time Schedule Pembangunan Gedung Perkantran \& Gudang Suzuya Medan Menggunakan Microsoft Project

Sumber : Microsoft Project

Beberapa item pekerjaan yang meleset dari jadwal perencaan setelah di evaluasi menggunakan Microsoft project.

Galian Tanah Pondasi, galian tanah diperdiksi selesai dalam 10 hari, sementara lamanya pengerjaan di lapangan adalah 14 hari, maka perencaan jadwal untuk selanjutnya ikut bergeser mundur akibat pekerjaan galian tanah yang terlambat sehingga membuat galian tersebut memasuki jalur kritis (warna merah),terlihat pada gambar 8 dibawah ini.

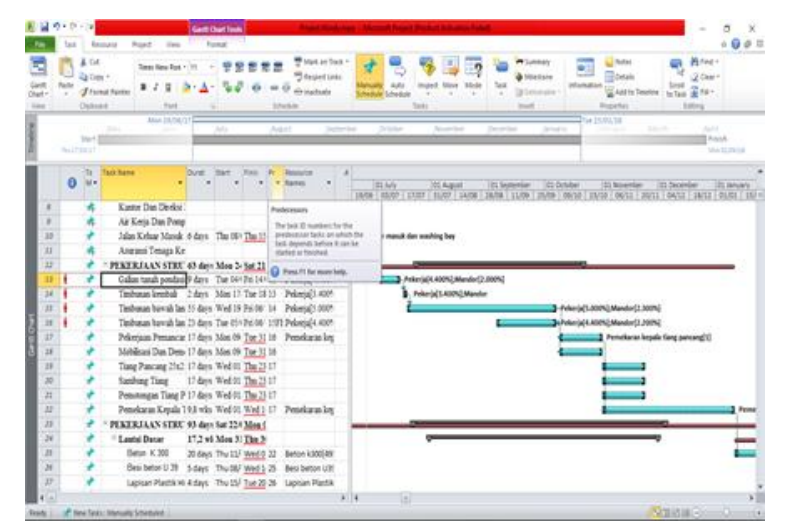

Gambar 8. Tampilan Realisasi Pekerjaan Galian Pondasi Sumber : Microsoft Project

Pada gambar 9 ini belum dimunculkan jalur kristis, tampilan gambar ini masih menunjukkan diagram batang berwarna biru.

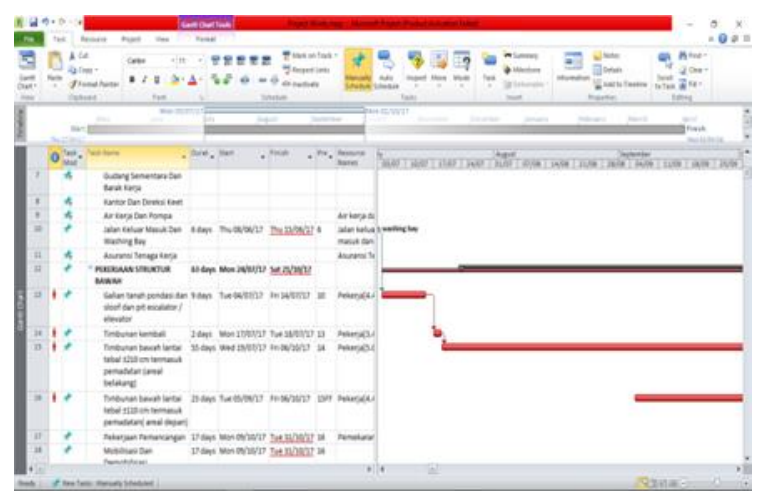

Gambar 9. Tampilan Realisasi Pekerjaan Galian Pondasi Keterangan : Warna merah adalah jalur kritis Sumber : Microsoft Project

Microsoft project yang menujukkan seluruh item kegiatan pada jalur kritis. Hal ini terlihat pada diagram batang warna merah setiap item pekerjaan.

Item pekerjaan yang terdapat pada jalur kritis yaitu pekerjaan galian tanah pondasi, timbunan kembali, timbunan bawah $\pm 210 \mathrm{~cm}$ dan $\pm 110 \mathrm{~cm}$ dan pekerjaan pemancangan.

\section{KESIMPULAN}

Hasil dari analisa pengendalian \& penjadwalan Proyek Pembangunan Gedung Perkantoran dan Gudang Suzuya Medan dapat disimpulkan bahwa Jadwal Rencana tidak sesuai dengan Jadwal Pelaksaan di Lapangan diketahui pekerjaan yang menujukkan jalur kritis seperti, pekerjaan pendahuluan, pekerjaan pondasi, dan pekerjaan pemasangan dinding berada di Jalur Kritis / Critical Path

Adapun faktor yang menjadi kendala pada saat pelaksanaan proyek adalah sering terjadi keterlambatan pengiriman barang sehingga pekerjaan 
tertunda dan menjadi mundur dari jadwal yang telah ditentukan.

\section{DAFTAR PUSTAKA}

Aliah. 2009. Penerapan Metode JaringanKerja Dlam Perencaan Waktu dan Biaya Pada Perusahaan Perumahan PT. Aryus Bersinar Lestari Jaya. Makasar. Tesis. Makasar : Universitas Hasanudin.

Dianas Perumahan. 2017. Daftar Harga Upah dan Bahan Daftar Analisa Harga Satuan. Medan : Dep Diknas Perumahan.

Kadir, Bdul. 2014. Pengenalan Sistem Informasi Edisi Revisi 2014. Jogyakarta : ANDI.

Nurhayati. 2010. Mananajemen Proyek. Yogyakarta : Graha Ilmu

Sitorus, Romauli Kristian. 2015. Perencaan dan Pengendalian Waktu Proyek Dengan Menggunakan Microsoft Project Pada Pembangunan Where House-2. Skripsi. Medan : Universitas Medan Area.

Soeharto, Iman. 1999. Manajemen Proyek : Dari Konseptual Sampai Oprasional. Jakarta : Erlangga.

Tanu Brata, maksum dan Marco Dirgahadi Lukman. 2011. SISTEM INFORMASI PENJADWALAN DAN PENGENDALIAN NIAYA PROYEK KONSTRUKSI. Jurnal Sipil Setatik. 1(1) : 22 - 26.

Tri Hendardi, C. 2011. Microsoft Project 2010 Pendekatan siklus proyek Langkah Cerdas Merencanakan dan Mengelola Proyek. Jogyakarta : ANDI.

Widya Santi, Irika dan Lenggo Geni. 2013. Manajemen Konstruksi. Bandung : PT. Remaja Rosda Karya. . 2018. Dokumen Pengadaan Jasa Konstruksi. Medan : Kemenaker. 2018. Manajemen Konstruksi. Medan : Kemenaker . 2018. Analisa Harga Satuan. Medan : Kemenaker. 